\title{
Fabrication process parameters significantly affect the perovskite oxygen carriers materials (OCM) performance in chemical looping with oxygen uncoupling (CLOU)
}

\author{
Yngve Larring $^{1}$ (1) - Mehdi Pishahang ${ }^{1,4} \cdot$ Julian Tolchard $^{1} \cdot$ Anna M. Lind ${ }^{1} \cdot$ Martin F. Sunding ${ }^{1} \cdot$ \\ Ruth E. Stensrød ${ }^{1} \cdot$ Marijke Jacobs $^{2} \cdot$ Frans Snijkers $^{2} \cdot$ Tjalling van der Kolk $^{3} \cdot$ Knuth Albertsen $^{3}$
}

Received: 7 December 2018/Accepted: 20 September 2019/Published online: 1 October 2019

(c) The Author(s) 2019

\begin{abstract}
The CLOU performance of the $\mathrm{CaTi}_{x} \mathrm{Mn}_{0.9-\mathrm{x}} \mathrm{Mg}_{0.1} \mathrm{O}_{3}$ (CMTM) perovskite-type system was investigated, comparing materials produced at laboratory scale with those made at industrial ton scale. The CLOU and conversion performances were studied by a micropacked bed reactor, and crystalline phase structure and homogeneity and bulk density identified as the most important parameters affecting the performance of the OCM. Bulk density is correlated with the sintering temperature, atmosphere and time at sintering temperature, while phase homogeneity is a function of the raw materials chosen, agglomeration method and sintering procedure. Specific challenges are identified in the control of slurry homogeneity and sintering conditions in upscaled production. The degree of sintering affects the chemo-mechanical properties of the material (crushing strength and attrition index), physical properties (specific surface area), and more importantly the crystalline phases formed and their homogeneity: the quantity of "active" crystalline phases present directly determines the thermochemical conversion properties (i.e., CLOU capacity and methane conversion), oxygen transfer capacity and kinetics.
\end{abstract}

Yngve Larring

Yngve.Larring@SINTEF.no

Mehdi Pishahang

mehdip@MIT.edu

1 SINTEF Industry, Sustainable Energy Technology, 0314 Oslo, Norway

2 VITO-Flemish Institute for Technological Research, 2400 Mol, Belgium

3 Euro Support Advanced Materials, Uden, The Netherlands

4 Present Address: Department of Mechanical Engineering, Massachusetts Institute of Technology, 77 Massachusetts Avenue, Cambridge, MA, USA 


\section{Graphic abstract}

The fabrication parameters of the otherwise same ingredients result in quite different morphology and quality of performance in large scale.
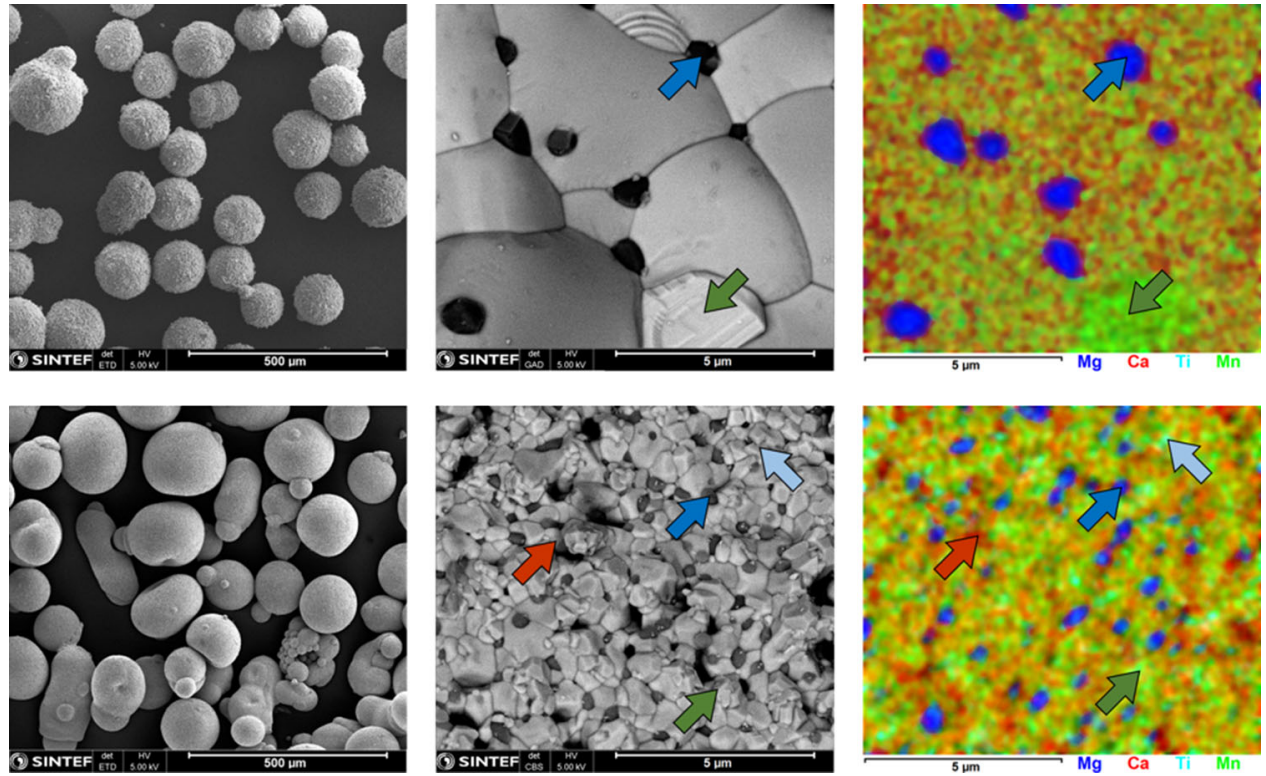

Keywords Calcium manganite $\cdot \mathrm{CaMnO}_{3} \cdot$ Sintering temperature $\cdot \mathrm{CLC} \cdot \mathrm{CLOU} \cdot \mathrm{TPX} \cdot$ Micropacked bed $\cdot$ In situ XRD · SEM

\section{Introduction}

The development of power generation technologies using conventional hydrocarbon fuels with carbon capture and storage (CCS) is a necessary solution to link the contemporary power technologies with environmental demands while all-renewable power technologies emerge. In this context, chemical looping combustion (CLC) is an interesting technology, as CLC allows higher efficiency and lower cost compared to other oxy-combustion technologies. In CLC, oxygen from the air is utilized indirectly in the combustion reactor (fuel reactor) via a solid oxygen carrier material (OCM) that cycles between an air reactor (where OCM takes up oxygen from air) and a fuel reactor (where OCM combusts the fuel). As it intrinsically purifies the used oxygen, it removes the necessity for a stand-alone cryogenic air separation unit.

The OCM is generally a binary, ternary or quaternary transition metal oxide, which utilizes the transition metal redox activity to uptake and release oxygen [1-3]. In the context of fast circulating fluidized bed CLC configuration, the OCM is subject to substantial chemo-mechanical stresses during the redox cycling, through which it must retain a high oxygen capacity, fast redox kinetics and good mechanical properties [4-6]. Furthermore, for industrial application the cost of materials must be low, the component elements abundant, and the active materials and their by-products must be environmentally benign and nontoxic. Considering this long list of demanding requirements, only a handful of materials are proven to pass these criteria.

It has been previously shown that $\mathrm{CaMnO}_{3-\delta}$ perovskite-type oxides constitute a promising family to be used as OCM. This family of perovskites is especially of interest for large CLC applications, due to low cost and wide abundance of $\mathrm{Ca}$ and $\mathrm{Mn}$ ores as well as their relatively small environmental impact [7-9]. The redox performance of undoped $\mathrm{CaMnO}_{3}$, however, deteriorates because of phase separation to $\mathrm{CaMn}_{2} \mathrm{O}_{4}$ and $\mathrm{Ca}_{2} \mathrm{MnO}_{4}$ $[10,11]$. Although undoped $\mathrm{CaMnO}_{3}$ perovskite oxide is still considered, it is more common to see doped calcium manganite in publications focusing on perovskite OCMs. On A-site doping, partial substitution of the calcium by strontium, barium and lanthanum [12, 13] is reported, as well as A-site-deficient compounds [14, 15]. More relevant and interesting is the doping of the transition metal on the 
B-site, with partial substitution of manganese by magnesium, iron, titanium, or a combination of two or more of them [14-25]. Although it has limited miscibility in the perovskite structure, magnesium has positive catalytic effect on the methane reforming. Doping up to $15 \%$ with iron is shown to improve the spontaneous oxygen release kinetics, and widen the operational temperature range [24]. The most important dopant is titanium, as stability of the perovskite structure is shown to be enhanced by substitution of $\mathrm{Ti}$ on the $\mathrm{B}$-site $[15,25,26]$. This is due to the higher enthalpy of formation of $\mathrm{CaTiO}_{3}$ compared to $\mathrm{CaMnO}_{3}$ [27], which stabilizes the perovskite structure at reducing conditions of the fuel reactor. $\mathrm{CaMn}_{1-\mathrm{x}} \mathrm{Ti}_{\mathrm{x}} \mathrm{O}_{3-\delta}$ has proven to have high activity with respect to $\mathrm{CH}_{4}$ reduction [28], and introduction of only $12.5 \%$ titanium on the B-site improves the spontaneous oxygen release kinetics [29]. Furthermore, it has been shown that it has good chemical stability and shows small dimensional changes upon redox cycling [30]. It is also observed that the re-oxidation is faster for Ti-substituted $\mathrm{CaMnO}_{3}$ at high temperatures [22], and additional Fe doping positively influences the reduction reaction rate and broadened the operation window of the OCM to lower temperatures as well as improve microstructural stability during redox cycling [16]. Although Ti-doping does not assist with the known sulfur intolerance of $\mathrm{CaMnO}_{3}$ [14, 20, 21], remedial technologies for reactivation of the poisoned OCM in situ (in the fuel reactor) are already developed [31].

The multi-national R\&D project SUCCESS is globally the largest project so far with rigorous focus on manufacturing and fabrication of oxygen carrier material particles upscaled to industrial scale. The CMT perovskite-type OCM is one of the selected OCM systems. MgO-doped $\mathrm{CaMn}_{1-\mathrm{x}} \mathrm{Ti}_{\mathrm{x}} \mathrm{O}_{3-\delta}$ is one of the materials of focus in SUCCESS [32], selected for upscaling and demonstration. In this study, we analyze the mechanical and thermochemical performance of the laboratory-scale and ton-scale OCMs with the nominal composition $\mathrm{CaMn}_{0.775} \mathrm{Ti}_{0.125}$ $\mathrm{Mg}_{0.1} \mathrm{O}_{3-\delta}$ fabricated in this project, and try to pinpoint and address some of the remaining challenges that are important to be considered in further upscaling to industrial production scale.

\section{Experimental}

\section{Materials synthesis and fabrication}

$\mathrm{CaMn}_{0.775} \mathrm{Ti}_{0.125} \mathrm{Mg}_{0.1} \mathrm{O}_{3}$ (CMTM) is perovskite-type oxides from the $\mathrm{CaMnO}_{3}$ family. Two OCM samples with the same nominal composition were manufactured and studied. The first sample was manufactured at laboratory scale by VITO using a semi-industrial spray-drying method. The second sample was manufactured at the ton scale by Euro Support using an industrial spray-drying technology. The description of manufacturing of both samples is as follows:

\section{Laboratory-scale batch CMTM}

Stoichiometric quantities of $\mathrm{MnO}_{2}, \mathrm{Ca}(\mathrm{OH})_{2}, \mathrm{MgO}$ and $\mathrm{TiO}_{2}$ were dispersed in deionized water. This suspension was then homogenized using a Netzsch horizontal attrition mill prior to spray drying. During spray drying, the waterbased suspension was continuously stirred with a propeller blade mixer while being pumped to the 2-fluid spray-dry nozzle, positioned in the lower cone part of the spray drier (type 6.3-SD, Niro, Denmark). The suspension was atomized into a large number of small droplets in the chamber of the spray drier, which was filled with hot air from the top, thus creating a mixed flow regime. As such, the droplets quickly achieve a spherical shape due to surface tension effects. In addition, the large surface-to-volume ratio of the droplets allows rapid water evaporation, resulting in dry particles which are subsequently separated from the hot air. After spray drying, the fraction within the required particle size range $(100-300 \mu \mathrm{m})$ was separated from the rest of the spray-dried product by sieving. To obtain oxygen carrier particles with sufficient mechanical strength and with the desired crystalline phases, sintering was performed in air at $1335^{\circ} \mathrm{C}$.

\section{Ton-scale batch CMTM}

Based on the process developed by VITO described above the spray drying process was upscaled to the ton scale by Euro Support Advanced Material B.V. In order to develop a stable industrial process, the stability of the raw mix slurry needed to be extended. This required substitution of $\mathrm{Ca}(\mathrm{OH})_{2}$ by $\mathrm{CaCO}_{3}$. In order to obtain the desired final particles size with a high yield ratio, a single fluid highpressure system was used in place of a 2 fluid spray-dry nozzle. This is known to give a sharper particle size distribution especially for bigger spheres as needed for the OCM production. In the high-pressure nozzle, the droplet formation is achieved by a combination of a nozzle plate through which the suspension is pressed via a swirl chamber that creates an additional circular movement in the suspension. The formation of the spheres is a function of the pressure, the nozzle size and the rheological properties of the suspension. Therefore, the change in atomization technology also required changes in the rheological behavior of the suspension in order to get a similar shape for the spheres. The rest of the spray-drying process was identical to the process of VITO. A calcination study of the material produced at Euro Support indicated an optimum firing temperature of $1310^{\circ} \mathrm{C}$ set, which was very 
close to the temperature optimized by VITO for a different kiln. The full sample was calcined in a stacked saggar configuration.

\section{Morphochemical characterization}

Samples were characterized before and after the redox cycling. The sieved materials were deposited on conductive adhesive tape and excess material gently blown off. Fieldemission gun scanning electron microscopy (FEG-SEM) characterization was performed on a Nova NanoSEM650 (FEI corp.). Images were acquired based on secondary electron (SE) detectors which show topographic contrast and back-scattered electron (BSE) which reflect the local density of the samples (high density induces high brightness). Elemental analysis and mapping was performed using an X-Max50 (Oxford instruments) energy-dispersive spectrometer (EDS) attached to the FEG-SEM instrument.

\section{Surface area measurement}

The sample's surface area was measured with a Quantachrome Monosorb instrument. Nitrogen was used as the carrier gas in a single-point BET surface area measurement. Prior to the measurement, the samples were preheated up to $150{ }^{\circ} \mathrm{C}$ with the same carrier gas.

\section{In situ XRD}

The X-ray diffraction (XRD) measurements were performed using a PANalytical Empyrean diffractometer equipped with a $\mathrm{CuK} \alpha$ radiation source $(\alpha=1.541874 \AA$ ) and a PIXcel ${ }^{3 \mathrm{D}}$ solid-state detector. Diffraction patterns were recorded over a $2 \theta$ range of $10^{\circ}-100^{\circ}$ in BraggBrentano geometry. An Anton Paar XRK 900 in situ hightemperature $\left(25-900{ }^{\circ} \mathrm{C}\right.$ ) and high-pressure (1-10 bar) reactor cell coupled to an automated gas switching system was used for the in situ XRD experiments. The in situ XRD measurements were performed at $900{ }^{\circ} \mathrm{C}$ with a gas flow of

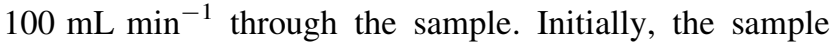

was heated up to $900{ }^{\circ} \mathrm{C}$ with a heating rate of $5{ }^{\circ} \mathrm{C} \min ^{-1}$ in synthetic air. The sample was kept at $900{ }^{\circ} \mathrm{C}$ in flowing air for $2 \mathrm{~h}$ before performing the XRD measurement. The gas was then switched to nitrogen, and the sample was kept in flowing nitrogen for $2 \mathrm{~h}$ before measurement. The sample was then cooled down to room temperature in nitrogen. XRD patterns were recorded at room temperature both before and after the experiment.

The crystalline phases present in the diffraction data were identified with reference to the ICDD PDF4+ database and quantitative Rietveld analysis performed using the Bruker DIFFRAC.SUITE Topas v5 software.

\section{Micropacked bed measurements}

Conversion measurements were performed from 800 to $950{ }^{\circ} \mathrm{C}$ with $50{ }^{\circ} \mathrm{C}$ incremental steps using a micropacked bed setup (MICROMERITICS AutoChem 2910 TPX apparatus and VG ProLab 1-300 amu mass spectrometer). This reactor has an intersection area of $\sim 1 \mathrm{~cm}^{2}$. Sieved material in the size range of $125-180 \mu \mathrm{m}$ was used, with $0.5 \pm 0.01 \mathrm{~g}$ of sample used in each experiment. The gas flow $\left(30 \mathrm{~mL} \mathrm{~min}{ }^{-1}\right.$ ) was successively set from oxidizing $\left(5 \% \mathrm{O}_{2}+5 \% \mathrm{~N}_{2}\right.$ in $\mathrm{He}$ for $60 \mathrm{~min}$ ) to inert (He for $30 \mathrm{~min})$ and from oxidizing $(30 \mathrm{~min})$ to reducing conditions $\left(10 \% \mathrm{CH}_{4}\right.$ in He for $5 \mathrm{~min}$ ) with a final inert step (100\% He for $10 \mathrm{~min}$ ). The composition of the outlet gas was followed by mass spectrometry in order to study the CLOU effect and conversion. The gas mixtures used in the experiments are summarized in Table 1.

\section{Results and discussion}

\section{Morphochemical structure of the fabricated materials}

As synthesized, the measured surface area for samples was $1<\mathrm{m}^{2} \mathrm{~g}^{-1}$. The laboratory-scale synthesized materials exhibited a density of $1841 \mathrm{~kg} \mathrm{~m}^{-3}$, while the industrial-

Table 1 Gas mixtures used in the atmospheric experiments

\begin{tabular}{|c|c|c|c|c|c|c|c|c|c|}
\hline \multicolumn{10}{|c|}{ Micro packed bed cycles $\left(800-950{ }^{\circ} \mathrm{C}\right.$ with $50{ }^{\circ} \mathrm{C}$ steps $)$} \\
\hline & \multirow[t]{2}{*}{ Step } & \multirow[t]{2}{*}{ Gas type } & \multirow[t]{2}{*}{ Time at setpoint (min) } & \multicolumn{6}{|c|}{ Gas concentration (vol\%) } \\
\hline & & & & $\mathrm{H}_{2}$ & $\mathrm{CH}_{4}$ & $\mathrm{~N}_{2}$ & $\mathrm{H}_{2} \mathrm{O}$ & $\mathrm{He}$ & $\mathrm{O}_{2}$ \\
\hline \multirow[t]{2}{*}{ Spontaneous oxygen release } & 1 & Oxidizing & 60 & - & - & 5 & - & 90 & 5 \\
\hline & 2 & Inert & 30 & - & - & - & - & 100 & - \\
\hline \multirow[t]{3}{*}{ Conversion activity } & 1 & Oxidizing & 30 & - & - & 5 & - & 75 & 20 \\
\hline & 2 & Reducing & 5 & - & 10 & - & - & 90 & - \\
\hline & 3 & Inert & 10 & - & - & - & - & 100 & - \\
\hline
\end{tabular}


Fig. 1 Microstructure and morpho-chemical mapping of laboratory-scale (up) and tonscale (bottom) CMTM samples. To the left low $(500 \mu \mathrm{m})$ and in the middle, average $(5 \mu \mathrm{m})$ magnification of the systems is shown. The EDS morphochemical mapping of constituent elements in average magnification is shown to the right

Fig. 2 Rietveld fit to the room temperature data for laboratoryscale CMTM sample. Phase peaks positions are indicated for (a) Mn-rich $\mathrm{CaMn}_{1-\mathrm{x}} \mathrm{Ti}_{\mathrm{x}} \mathrm{O}_{3}$, (b) $\mathrm{MgO}$, (c) Ti-rich $\mathrm{CaMn}_{1-\mathrm{x}} \mathrm{Ti}_{\mathrm{x}} \mathrm{O}_{3}$, (d) $\mathrm{CaMn}_{2} \mathrm{O}_{4}$ and (e) $\mathrm{Ca}_{2} \mathrm{MnO}_{4}$
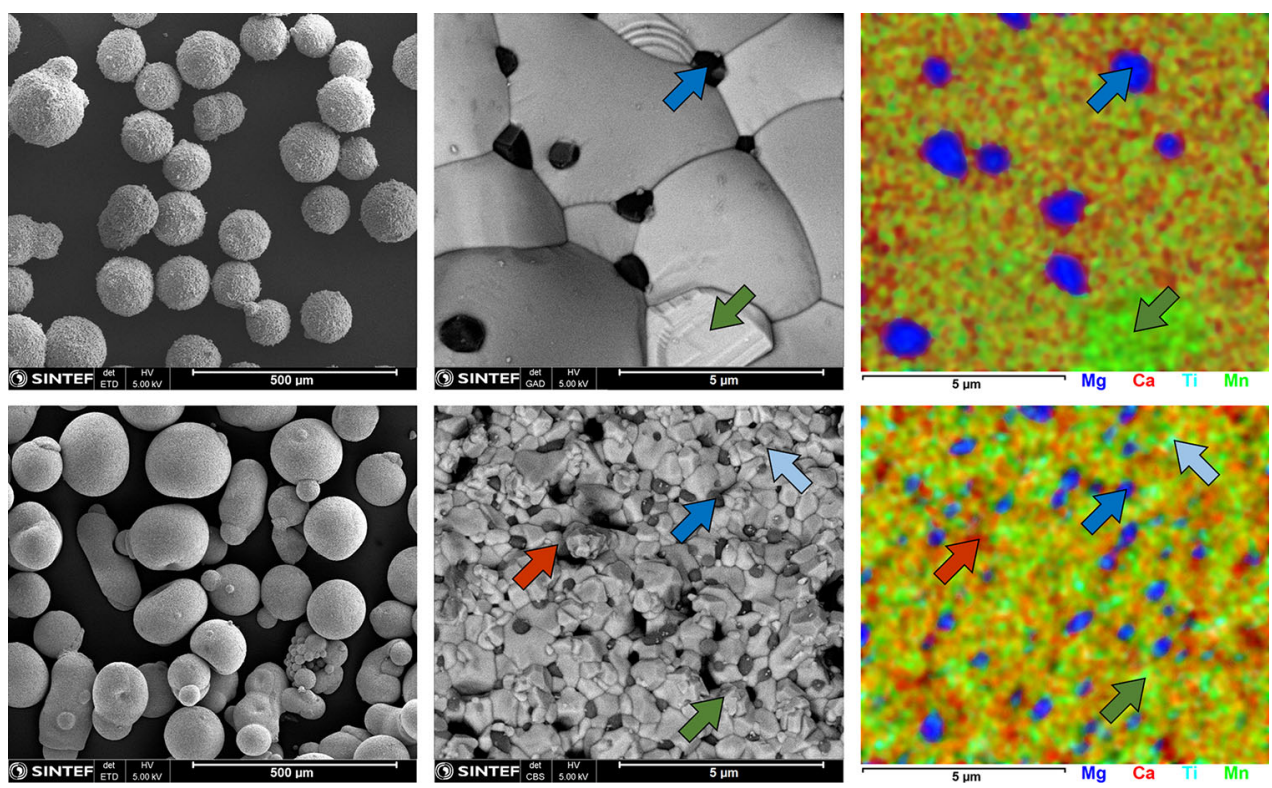

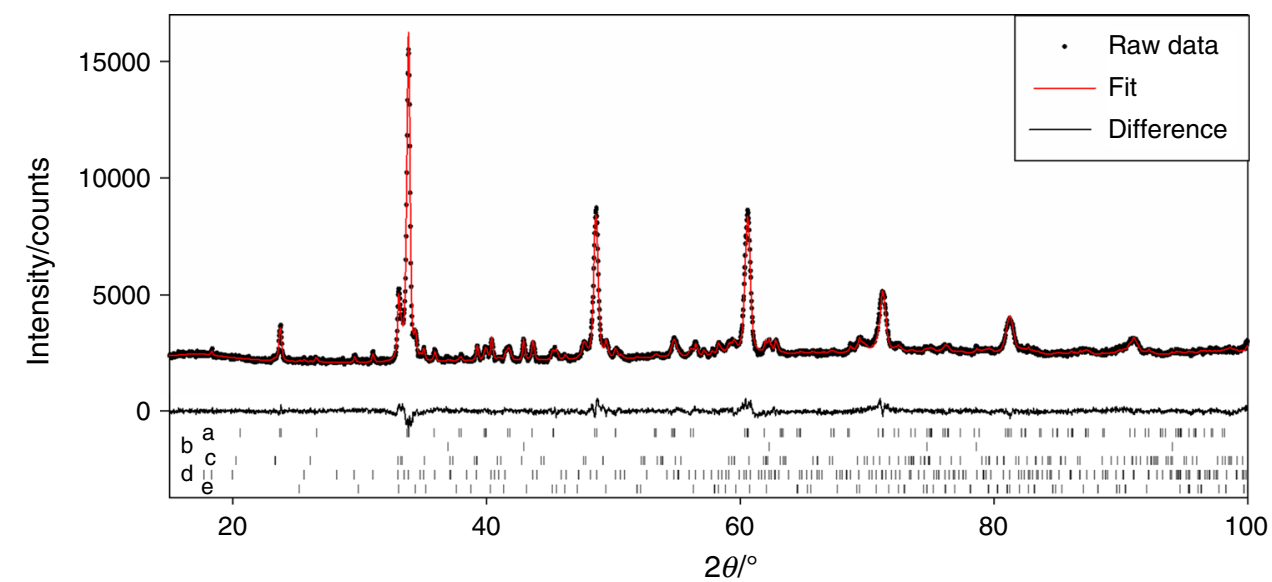

scale synthesized materials showed a significantly higher bulk density of 2200 to $2400 \mathrm{~kg} \mathrm{~m}^{-3}$. Figure 1 shows the SEM-EDS imaging of the laboratory-scale and ton-scale CMTM.

It is seen that the individual particles for both systems are highly spherical and uniform, with agglomerate particle sizes in range $80-180 \mu \mathrm{m}$. High-magnification back-scattered electron images confirm that the microstructure and present phases are, however, different.

The fresh laboratory-scale CMTM material is highly spherical and contains minimal doughnut or necking. Higher-resolution images indicate that the grain sizes are in the range of 5 to $10 \mu \mathrm{m}$. X-ray diffraction measurements support the SEM-EDS results and suggest that the predominant phase in the sample is a perovskite of approximate stoichiometry of $\mathrm{CaTi}_{0.15} \mathrm{Mn}_{0.85} \mathrm{O}_{3}$ (Fig. 2 and Table 2). The magnesium oxide observed by XRD is clearly evident in the EDS element maps (blue areas in Fig. 1), and the elemental analysis confirms that $\mathrm{Mg}$ is not dissolved in the perovskite matrix structure. The element analysis also reveals separate Ti-rich and Mn-rich areas, supporting the coexistence of calcium manganate phases with the calcium manganese titanate observed by XRD.

The microstructure and morpho-chemical mapping of fresh ton-scale CMTM samples are also presented in Fig. 1. Although similar in nominal composition, this material differs from laboratory-scale synthesized sample in microstructure and grain sizes. The material's sphericity is less than that of the laboratory-scale sample, and some necking and doughnut particles are observed. The microstructure is also quite different, and the grain sizes are much smaller. The sample is also inhomogeneous with respect to composition, with $\mathrm{Ca}-\mathrm{Mn}$ - and Ti-rich areas evident in the elemental mapping. Despite the relatively 
Table 2 Structure and phase fractions for laboratory-scale CMTM at room temperature before reaction

\begin{tabular}{|c|c|c|}
\hline Phase & Unit cell $25^{\circ} \mathrm{C}$ & Phase fraction $25^{\circ} \mathrm{C}$ (mass $\%$ ) \\
\hline $\mathrm{CaMn}_{1-\mathrm{x}} \mathrm{Ti}_{\mathrm{x}} \mathrm{O}_{3}(x \approx 0.1-0.2)$ & $\begin{array}{l}\mathrm{SG}=\mathrm{Pbnm}(62) \\
a=5.2872(3) \AA \\
b=5.3127(4) \AA \\
c=7.4729(5) \AA \\
\mathrm{vol}=209.91(3)\end{array}$ & $69.0(4)$ \\
\hline $\mathrm{CaMn}_{1-\mathrm{x}} \mathrm{Ti}_{\mathrm{x}} \mathrm{O}_{3}(x \approx 0.9-1)$ & $\begin{array}{l}\mathrm{SG}=\operatorname{Pbnm}(62) \\
a=5.3609(19) \AA \\
b=5.4120(23) \AA \\
c=7.6258(34) \AA \\
\text { vol }=221.25(16)\end{array}$ & $8.2(3)$ \\
\hline $\mathrm{Ca}_{2} \mathrm{MnO}_{4}$ & $\begin{array}{l}\mathrm{SG}=\mathrm{I} 41 / \mathrm{acd}(142) \\
a=5.2117(5) \AA \\
c=23.8989(45) \AA \\
\mathrm{vol}=649.1(2)\end{array}$ & $7.2(3)$ \\
\hline $\mathrm{CaMn}_{2} \mathrm{O}_{4}$ & $\begin{array}{l}\mathrm{SG}=\operatorname{Pbcm}(57) \\
a=3.1615(4) \AA \\
b=9.9878(13) \AA \\
c=9.6647(12) \AA \\
\text { vol }=305.18(7)\end{array}$ & $12.0(3)$ \\
\hline $\mathrm{MgO}$ & $\mathrm{SG}=\mathrm{Fm}-3 \mathrm{~m}(225)$ & $3.5(2)$ \\
\hline
\end{tabular}

Fig. 3 Rietveld fit to the $900{ }^{\circ} \mathrm{C} / \mathrm{N}_{2}$ data for laboratoryscale CMTM sample. Phase peaks positions are indicated for (a) Mn-rich $\mathrm{CaMn}_{1-\mathrm{x}} \mathrm{Ti}_{\mathrm{x}} \mathrm{O}_{3}$, (b) $\mathrm{MgO}$, (c) Ti-rich $\mathrm{CaMn}_{1-\mathrm{x}} \mathrm{Ti}_{\mathrm{x}} \mathrm{O}_{3}$, (d) $\mathrm{CaMn}_{2} \mathrm{O}_{4}$ and (e) $\mathrm{Ca}_{2} \mathrm{MnO}_{4}$. Inset is a magnification of the $32-42^{\circ} 2 \theta$ region with the positions marked of the (absent) diffraction lines which arise from oxygen octahedral tilting

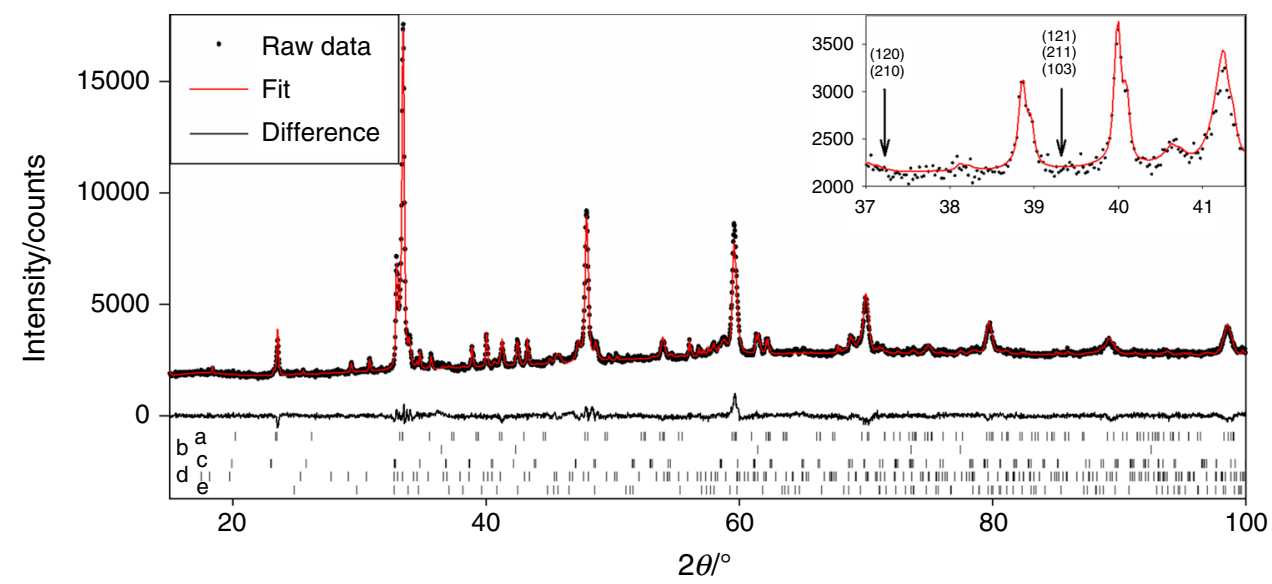

Table 3 Pseudo-cubic lattice parameters for the Mn-rich $\mathrm{CaMn}_{1-\mathrm{x}}$ $\mathrm{Ti}_{\mathrm{x}} \mathrm{O}_{3}$ phase

\begin{tabular}{lll}
\hline $\begin{array}{l}\text { Pseudo-cubic cell } \\
\text { parameters at } \\
25{ }^{\circ} \mathrm{C}\end{array}$ & $\begin{array}{l}\text { Pseudo-cubic cell } \\
\text { parameters at } 900{ }^{\circ} \mathrm{C} \\
\text { in air }\end{array}$ & $\begin{array}{l}\text { Pseudo-cubic cell } \\
\text { parameters at } 900{ }^{\circ} \mathrm{C} \\
\text { in } \mathrm{N}_{2}\end{array}$ \\
\hline$a_{\mathrm{c}}=3.7386 \AA$ & $a_{\mathrm{c}}=3.8031 \AA$ & $a_{\mathrm{c}}=3.8285 \AA$ \\
$a_{\mathrm{b}}=3.7566 \AA$ & $a_{\mathrm{b}}=3.7854 \AA$ & $a_{\mathrm{b}}=3.8063 \AA$ \\
$a_{\mathrm{c}}=3.7365 \AA$ & $a_{\mathrm{c}}=3.7829 \AA$ & $a_{\mathrm{c}}=3.8062 \AA$ \\
\hline
\end{tabular}

Values are calculated as $a_{\mathrm{c}}=a_{\text {orth }} / \sqrt{ } 2, a_{\mathrm{b}}=b_{\text {orth }} / \sqrt{ } 2, a_{\mathrm{c}}=c_{\text {orth }} / 2$

higher density, a lower level of reaction is indicated by the microstructure. It is noted that the mechanical strength is equivalent to that of laboratory-scale batch.

\section{In situ XRD}

In situ XRD was performed only on the laboratory-scale CMTM material. This was performed at $900{ }^{\circ} \mathrm{C}$ in air, and subsequently in $\mathrm{N}_{2}$ following an isothermal gas change. The summary of identified phases at room temperature is given in Table 2, with corresponding Rietveld fit to the data shown in Fig. 2. The identified phases and their relative fractions at $900{ }^{\circ} \mathrm{C}$ are given in Table 4, with a corresponding Rietveld fit of the data collected in $\mathrm{N}_{2}$ given in Fig. 3.

As prepared, the sample comprises a major phase of $\mathrm{CaMn}_{1-\mathrm{x}} \mathrm{Ti}_{\mathrm{x}} \mathrm{O}_{3}$ (orthorhombic perovskite), $\mathrm{Ca}_{2} \mathrm{MnO}_{4}$ $\left(\mathrm{K}_{2} \mathrm{NiF}_{4}\right.$ structure [33]) and $\mathrm{CaMn}_{2} \mathrm{O}_{4}$ (Marokite [34]), 
Table 4 Structure and phase fractions for laboratory-scale CMTM at $900{ }^{\circ} \mathrm{C}$ in air and $\mathrm{N}_{2}$

\begin{tabular}{|c|c|c|c|c|}
\hline Phase & Unit cell $900{ }^{\circ} \mathrm{C}$ in air & $\begin{array}{l}\text { Phase fraction } \\
900{ }^{\circ} \mathrm{C} \text { in air }\end{array}$ & Unit cell $900{ }^{\circ} \mathrm{C}$ in $\mathrm{N}_{2}$ & $\begin{array}{l}\text { Phase fraction } \\
900{ }^{\circ} \mathrm{C} \text { in } \mathrm{N}_{2}\end{array}$ \\
\hline $\mathrm{CaMn}_{1-\mathrm{x}} \mathrm{Ti}_{\mathrm{x}} \mathrm{O}_{3}(x \approx 0.1-0.2)$ & $\begin{array}{l}\mathrm{SG}=\operatorname{Pbnm}(62) \\
a=5.3784(4) \AA \\
b=5.3533(4) \AA \\
c=7.5657(5) \AA \\
\mathrm{vol}=217.83(3)\end{array}$ & $77.3(7)$ & $\begin{array}{l}\mathrm{SG}=\mathrm{Pbnm}(62) \\
a=5.4143(13) \AA \\
b=5.3829(4) \AA \\
c=7.6124(4) \AA \\
\mathrm{vol}=221.86(6)\end{array}$ & $62.8(5)$ \\
\hline $\mathrm{CaMn}_{1-\mathrm{x}} \mathrm{Ti}_{\mathrm{x}} \mathrm{O}_{3}(x \approx 0.8-1)$ & $\begin{array}{l}\mathrm{SG}=\mathrm{Pbnm}(62) * \\
a=5.4446 \AA^{*} \\
b=5.4639 \AA^{*} \\
c=7.7217 \AA^{*} \\
\mathrm{vol}=229.71 *\end{array}$ & $7.1(3)$ & $\begin{array}{l}\mathrm{SG}=\operatorname{Pbnm}(62) * \\
a=5.4446 \AA^{*} \\
b=5.4639 \AA^{*} \\
c=7.7217 \AA^{*} \\
\text { vol }=229.71^{*}\end{array}$ & $7.8(5)$ \\
\hline $\mathrm{Ca}_{2} \mathrm{MnO}_{4}$ & $\begin{array}{l}\mathrm{SG}=\mathrm{I} 41 / \mathrm{acd}(142) \\
a=5.2952(5) \AA \\
c=23.9781(46) \AA \\
\mathrm{vol}=672.34(19)\end{array}$ & $4.6(3)$ & $\begin{array}{l}\mathrm{SG}=\mathrm{I} 41 / \mathrm{acd}(142) \\
a=5.3066(4) \AA \\
c=23.9609(42) \AA \\
\mathrm{vol}=674.75(16)\end{array}$ & $9.9(4)$ \\
\hline $\mathrm{CaMn}_{2} \mathrm{O}_{4}$ & $\begin{array}{l}\mathrm{SG}=\operatorname{Pbcm}(57) \\
a=3.2092(9) \AA \\
b=10.1149(32) \AA \\
c=9.7245(28) \AA \\
\mathrm{vol}=315.66(16)\end{array}$ & $7.5(5)$ & $\begin{array}{l}\mathrm{SG}=\mathrm{Pbcm}(57) \\
a=3.2093(2) \AA \\
b=10.1151(7) \AA \\
c=9.7424(6) \AA \\
\mathrm{vol}=316.26(3)\end{array}$ & $14.7(3)$ \\
\hline $\mathrm{MgO}$ & $\begin{array}{l}\mathrm{SG}=\mathrm{Fm}-3 \mathrm{~m}(225) \\
a=4.2639(5) \\
\mathrm{vol}=77.52(3)\end{array}$ & $3.4(3)$ & $\begin{array}{l}\mathrm{SG}=\mathrm{Fm}-3 \mathrm{~m}(225) \\
a=4.2715(4) \\
\mathrm{vol}=77.94(2)\end{array}$ & $4.8(3)$ \\
\hline
\end{tabular}

*Due to instability in fitting, unit cell parameters for $\mathrm{CaTiO}_{3}$ were locked to values obtained by Yashima and Ali at $900{ }^{\circ} \mathrm{C}$ [36]

with small amounts of a second orthorhombic perovskite and $\mathrm{MgO}$ also present. The fitted room temperature unit cell parameters for the major perovskite phase correlate well to a composition $x \approx 0.1-0.2$ in $\mathrm{CaMn}_{1-\mathrm{x}} \mathrm{Ti}_{\mathrm{x}} \mathrm{O}_{3}$ [35]. The minor perovskite phase exhibits unit cell dimensions close to those reported for $\mathrm{CaTiO}_{3}$ [36] and so is presumed to be a Ti-rich member of the same solid solution.

On heating to $900{ }^{\circ} \mathrm{C}$ in air, $\mathrm{CaMn}_{2} \mathrm{O}_{4}$ and $\mathrm{Ca}_{2} \mathrm{MnO}_{4}$ are observed to react into the $\mathrm{CaMn}_{1-\mathrm{x}} \mathrm{Ti}_{\mathrm{x}} \mathrm{O}_{3}$ phase. The orthorhombic distortion of this phase is also reduced with increasing temperature, as reflected by the pseudo-cubic unit cell parameters for the room temperature and $900{ }^{\circ} \mathrm{C}$ data (Table 3). Switching atmosphere from air to $\mathrm{N}_{2}$ at $900{ }^{\circ} \mathrm{C}$ induces a marked increase of $\sim 1.85 \%$ in the unit cell volume for the main $\mathrm{CaMn}_{1-\mathrm{x}} \mathrm{Ti}_{\mathrm{x}} \mathrm{O}_{3}$ phase (Table 4). Though this phase still shows apparent orthorhombicity in the unit cell parameters, it is also observed that the diffraction lines arising from the oxygen octahedral tilting located at $\sim 37.9^{\circ} 2 \theta$ (indices (120) and (210)) and at $\sim 39.2^{\circ} 2 \theta$ (indices (121), (211) and (103)) disappear completely, which suggests that the structure has probably transformed from orthorhombic to cubic. It is reported by Taguchi [33] that $\mathrm{CaMnO}_{3}$ undergoes an orthorhombic to

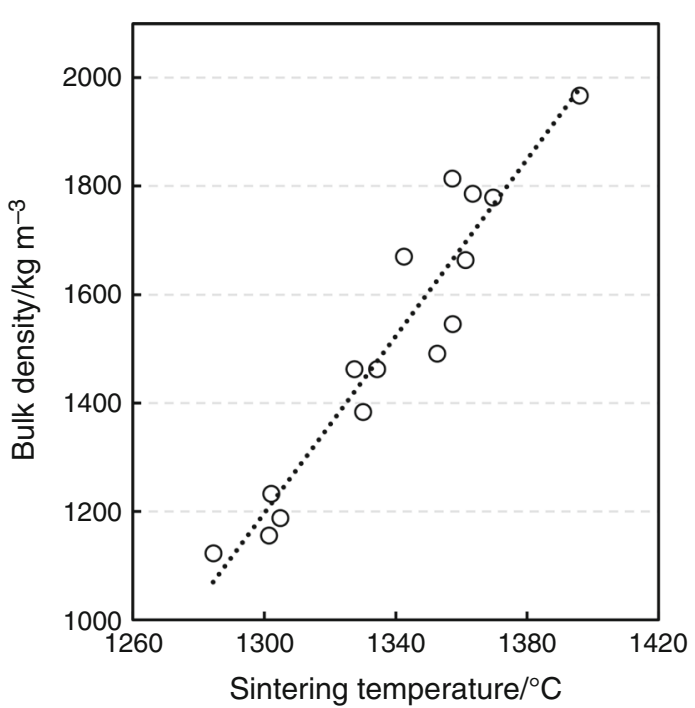

Fig. 4 Effect of sintering temperature on the bulk density of the produced OCM

tetragonal phase transition at $896{ }^{\circ} \mathrm{C}$, with a further transition from tetragonal to cubic at $913{ }^{\circ} \mathrm{C}$. Though solution of $\mathrm{Ti}$ into $\mathrm{CaMnO}_{3}$ would be expected to raise these transition temperatures [36], our observation is in good 
qualitative accord with the results of Leonidova et al. [37], who report strong depression of the transition temperatures in pure $\mathrm{CaMnO}_{3}$ with decreasing $\mathrm{pO}_{2}$. A slight shift in the relative phase fractions is also observed on switching from air to $\mathrm{N}_{2}$, with increases in the fractions of $\mathrm{Ca}_{2} \mathrm{MnO}_{4}$ and $\mathrm{CaMn}_{2} \mathrm{O}_{4}$ and a decrease in the major $\mathrm{CaMn}_{1-\mathrm{x}} \mathrm{Ti}_{\mathrm{x}} \mathrm{O}_{3}$ fraction. $\mathrm{CaMnO}_{3}$ is known to be unstable in reducing conditions with respect to $\mathrm{Ca}_{2} \mathrm{MnO}_{4}$ and $\mathrm{CaMn}_{2} \mathrm{O}_{4}$ [10].

\section{Parameters affecting sintering}

The most important parameters affecting sintering are temperature, time and atmosphere. These parameters were investigated in depth for this system Jing et al. [38] showed that temperature has the greatest effect on the quality of the final product and that after 5-6-h sintering, the effect of time is minimal. It was also shown that for upscaled calcination, an air atmosphere should be used. In Fig. 4, the effect of sintering temperature on the bulk density of a wide range of ton-scale CMTM samples is summarized, and demonstrates the sensitivity of the bulk density to the processing temperature, with only a $100{ }^{\circ} \mathrm{C}$ variation in the sintering temperature from 1280 to $1380{ }^{\circ} \mathrm{C}$ causing the bulk density to increase from $\sim 1150 \mathrm{~kg} \mathrm{~m}^{-3}$ to nearly $2000 \mathrm{~kg} \mathrm{~m}^{-3}$.

As the firing temperature is closely correlated with crystalline phases formed and their homogeneity, as well as the sample density, it primarily defines most of the performance characteristics of the CMTM OCM: Selectivity and activity toward chemical reactions such as methane conversion are a function of the crystalline phases present and their available surface area, and mechanical properties such as attrition index (through changing the crushing strength) are a function of sample density (Fig. 5). A difficult balance is then sought, which trades density (and thus strength) for increased surface area (and thus increased activity), while ensuring the presence of the correct crystalline phases. To achieve the optimum balance, samples must be processed within a relatively narrow sintering temperature window. The significantly higher density obtained for the ton-scale sample here, despite successful pre-sintering studies to determine the optimum firing temperature, highlights the difficulties with maintaining a homogenous and controlled thermal regime when upscaling.

\section{Micropacked bed reactor}

In order to study CLOU, redox performance and differences in the reaction rates of the two CMTM samples, pulsed and continuous analyses are performed in a micropacked bed reactor. The CLOU performance and sufficient CLOU capacity are essential for ensuring full combustion.
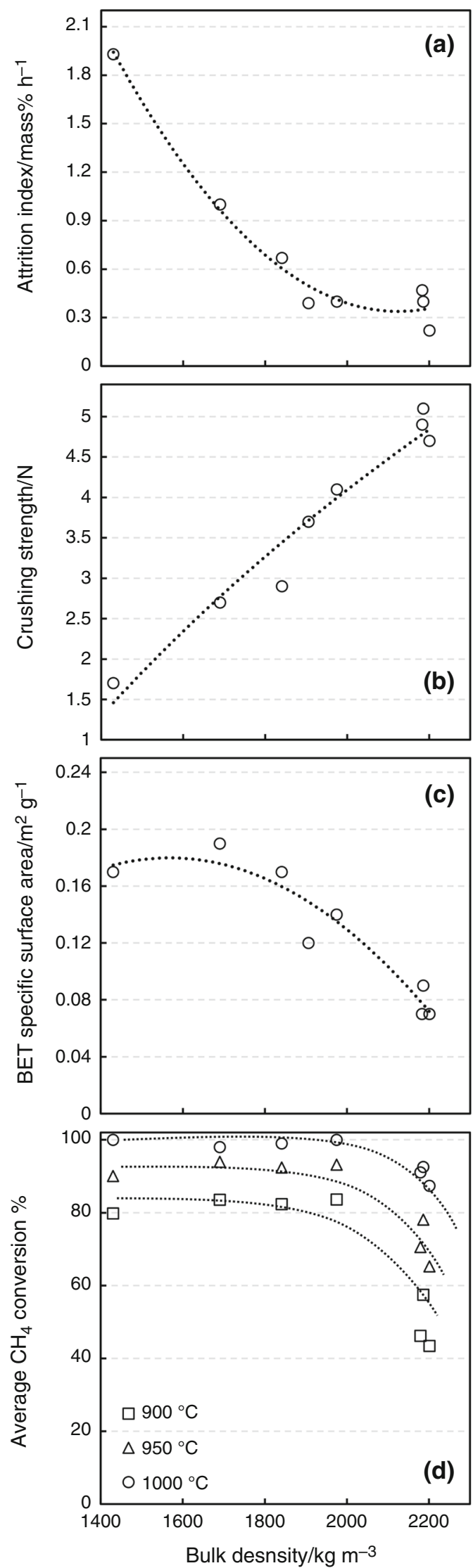
4Fig. 5 Effect of OCM's bulk density on parameters defining OCM's performance in the CLC process: a attrition index, $\mathbf{b}$ crushing strength, $\mathbf{c}$ specific surface area and $\mathbf{d}$ average methane conversion at 900,950 and $1000{ }^{\circ} \mathrm{C}$. The attrition and conversion values are extracted from [23]

For the CLOU experiment, the oxygen uptake and release experiment is measured, using gas switching sequences of $60 \mathrm{~min}$ of oxidizing oxygen uptake $\left(5 \% \mathrm{~N}_{2}\right.$ and $5 \% \mathrm{O}_{2}$ in $\mathrm{He}$ ) followed by $32 \mathrm{~min}$ of inert atmosphere $(100 \% \mathrm{He})$, and finally $30 \mathrm{~min}$ re-oxidation $\left(5 \% \mathrm{~N}_{2}\right.$ and $5 \% \mathrm{O}_{2}$ in $\mathrm{He}$ ). The results for both samples are summarized in Fig. 6. The left part of this figure shows the CLOU effect (oxygen release) under $\mathrm{He}$ inert condition, while the right part shows the re-oxidation (oxygen uptake). Considering the equal amounts of $\mathrm{O}_{2}$ and $\mathrm{N}_{2}$ in the oxidizing gas prior to and after the inert step, the difference between the $\mathrm{O}_{2}$ and $\mathrm{N}_{2}$ graphs corresponds to the oxygen CLOU capacity of the sample. Performing both oxygen release and uptake steps allows calculation of the samples' CLOU effect in two ways, from both released oxygen and from uptaken oxygen. It is clear from Fig. 6 that the $\mathrm{N}_{2}$ concentration in the gas has a constant dependency versus time, regardless of temperature or the OCM used in the reactor, and as $\mathrm{N}_{2}$ does not participate in any chemical reaction, the relaxation and response graphs for $\mathrm{N}_{2}$ are only dependent on physical and geometrical characteristics of the reactor. Therefore, at any time, the $\mathrm{N}_{2}$ concentration can be used as a reference.
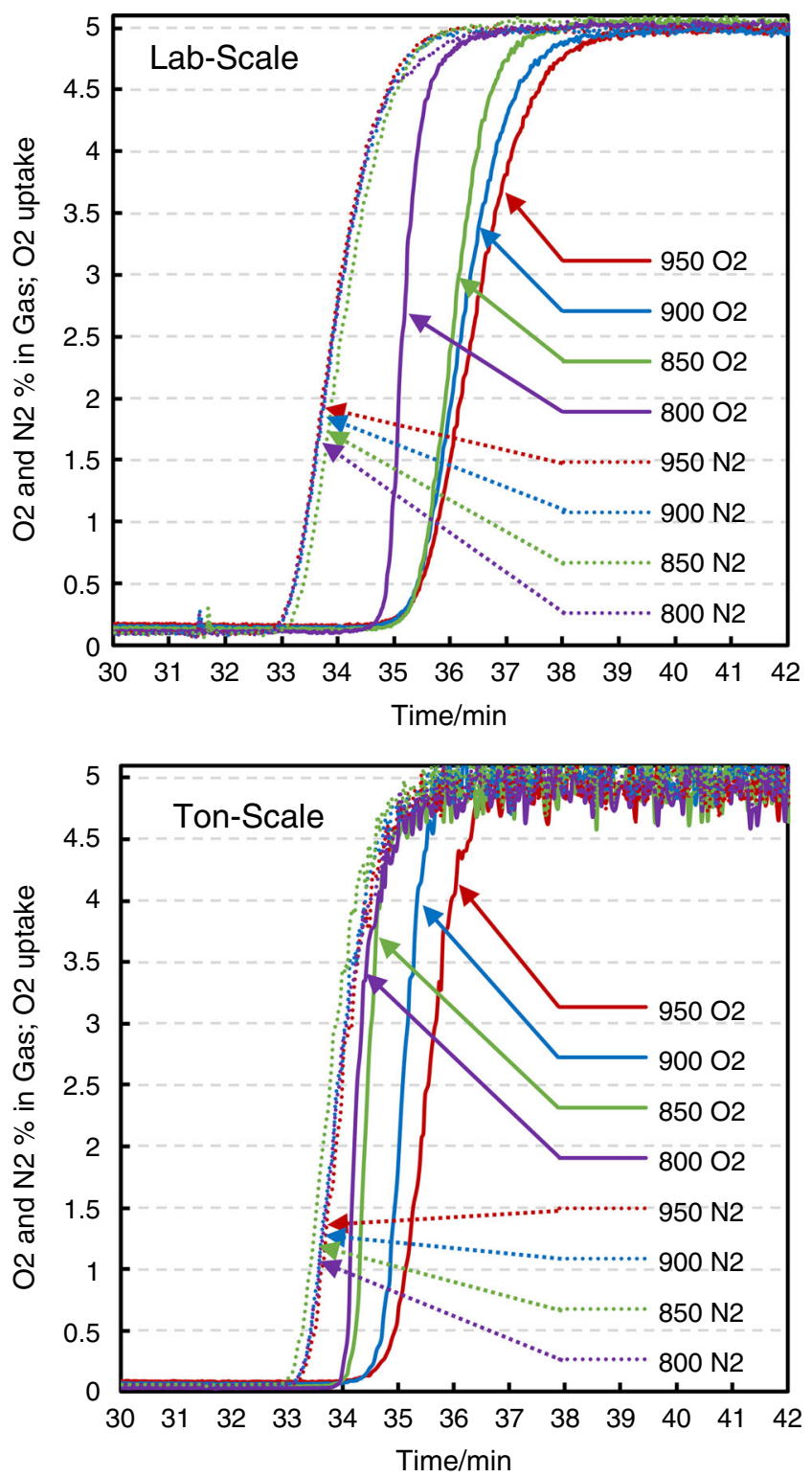

Fig. 6 Oxygen release in He CLOU (left) and oxygen uptake during oxidation (right) for laboratory-scale (top) and ton-scale (bottom) samples 

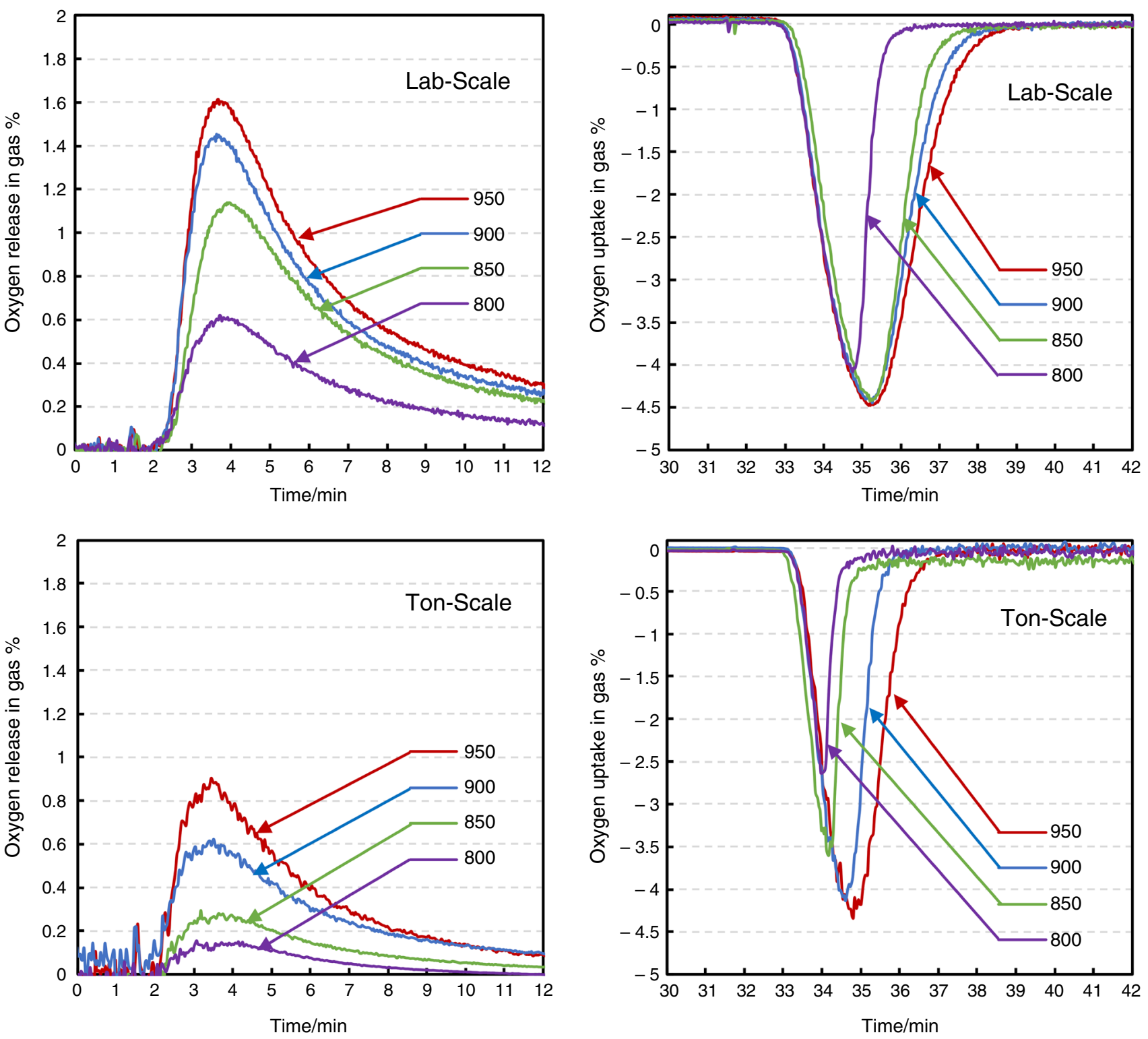

Fig. 7 a Released and consumed oxygen versus time, b integration of oxygen released under reduction in He and consumed under oxidation. CLOU release capacity as a function of temperature in $\mathrm{He}$ up to $30 \mathrm{~min}$ for the temperatures from 800 to $950{ }^{\circ} \mathrm{C}$

By applying this reference, via subtraction of $\mathrm{N}_{2}$ Fig. 7 is obtained. The CLOU capacity for the materials based on reduction was found to fit well with the CLOU capacity measured from the OCM's re-oxidization. From Fig. 7, it is clear that the oxidation which is much quicker and where background noise is not a part of the subtraction is the best way to establish the CLOU capacity.

As the nominal composition of both samples is equal, it is clear that the better homogeneity and lower density of the laboratory-scale sample result in better CLOU performance than for the ton-scale sample.

The CLOU capacity estimated from fixed bed oxygen release and oxygen absorption processes was found to be in the same range with a deviation varying between 1 and $8 \%$.
Figure 8 shows the CLOU capacity plotted versus temperature for oxygen release over a period of $30 \mathrm{~min}$ at different temperatures $\left(800-950{ }^{\circ} \mathrm{C}\right)$. The CLOU capacity decreases with decreasing temperature, and the laboratoryscale material has the highest CLOU capacity at all the temperatures of study. This is due to an increased fraction of CMT perovskite structure in this sample. The ton-scale sample exhibits much lower CLOU capacity compared to its nominal value, due to its lack of complete intermixing and unreactive $\mathrm{CaO}$ left over in the structure.

Experiments using $\mathrm{CH}_{4}$ as reductant were also performed on both samples. Reduction was performed under $10 \% \mathrm{CH}_{4}$ in $\mathrm{He}$ followed by oxidation under $5 \% \mathrm{~N}_{2}$ and $5 \% \mathrm{O}_{2}$ in $\mathrm{He}$. The results for this are shown for both 


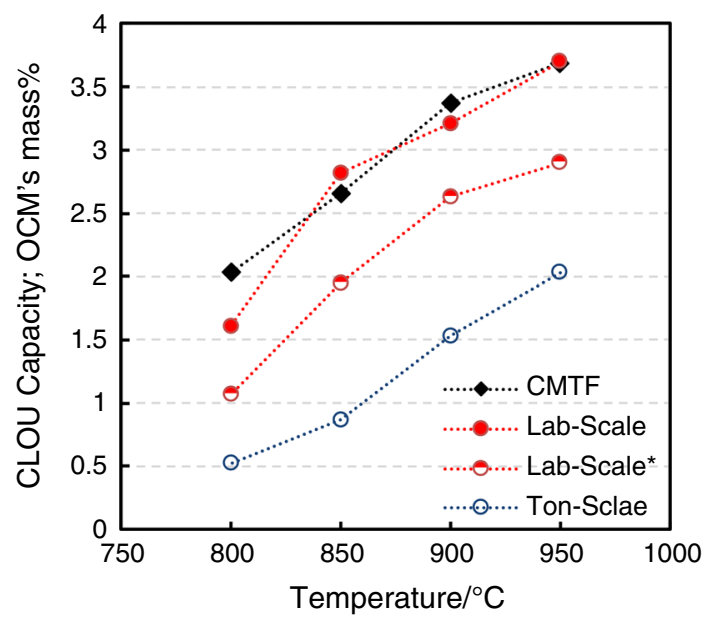

Fig. 8 CLOU capacity of the selected OCMs at different temperatures obtained from the micropacked bed experiments. Combustion of $10 \% \mathrm{CH}_{4}$ shows that for this fixed bed approach is the oxygen release rate limiting for methane conversion. Very small reforming activities are observed. The CMTF data correspond to $\mathrm{CaMn}_{0.725} \mathrm{Fe}_{0.15} \mathrm{Ti}_{0.125} \mathrm{O}_{3}$ sample and are extracted from [16]. The laboratory-scale* sample corresponds to $\mathrm{Ca}$ deficient laboratory-scale sample $\mathrm{Ca}_{0.95} \mathrm{Mn}_{0.775} \mathrm{Ti}_{0.125} \mathrm{Mg}_{0.1} \mathrm{O}_{3}$

samples in Fig. 9. This figure focuses only on the reduction part and shows the concentration of $\mathrm{CO}_{2}$ in outlet gases during reduction with methane. This confirms the lower CLOU capacity for the ton-scale sample, as the $\mathrm{CH}_{4}$ conversion is also lower compared to the laboratory-scale one. This difference is particularly pronounced at lower temperatures where the bulk oxygen diffusion is significantly lower, and cannot balance for the smaller specific surface area of this sample.

\section{Conclusions}

The formed crystalline phases, their homogeneity and achieved bulk density are identified as the most important parameter affecting the performance of the OCM. Bulk density is directly and significantly correlated with the sintering temperature, under the applied conditions. In other words, most of the important parameters defining the performance of the perovskite OCM are decided by the sintering temperature (if time and atmosphere are kept constant). These parameters include crushing strength, attrition index, specific surface area, CLOU capacity and gas conversion. One of the great challenges in upscaling of
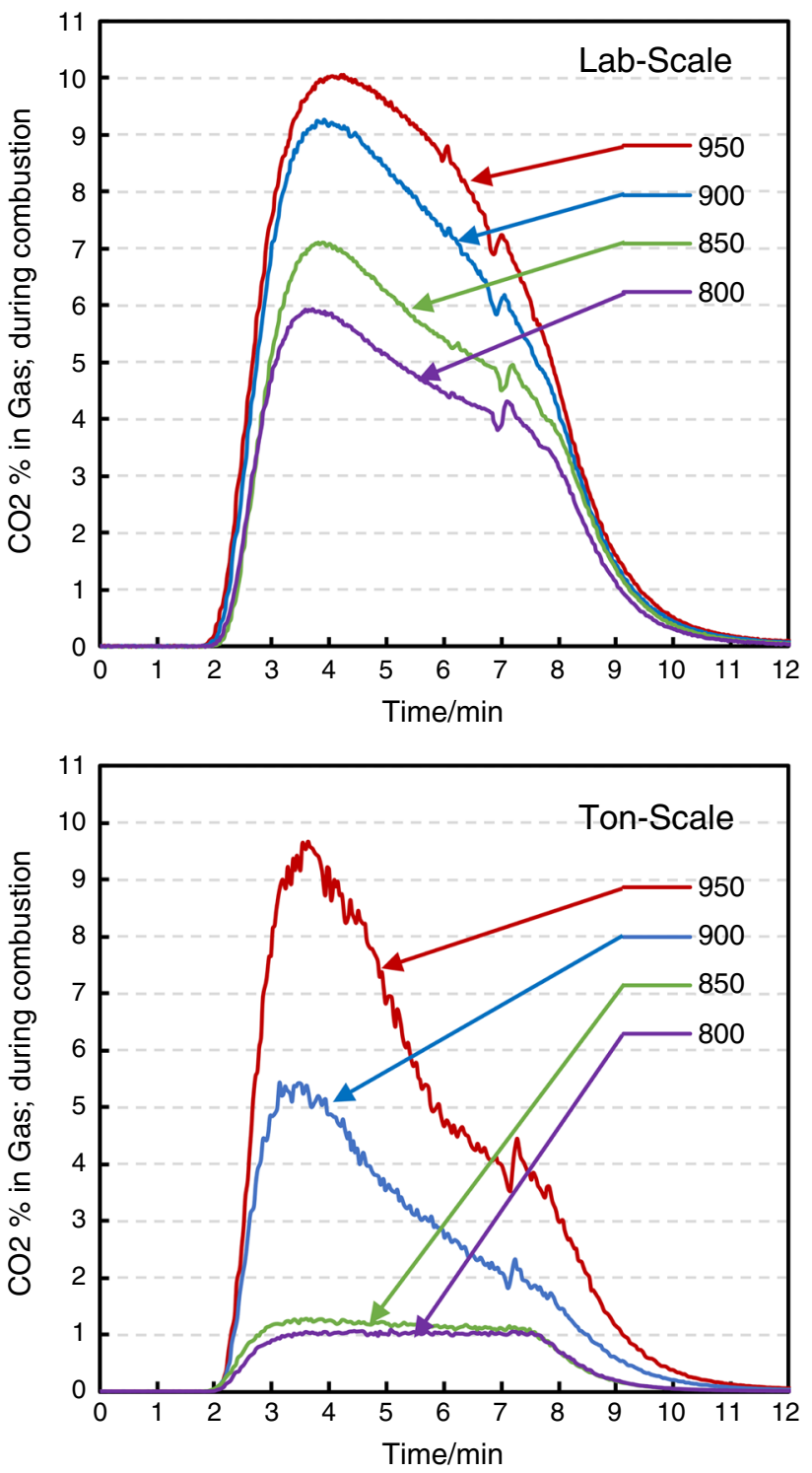

Fig. 9 Concentration of $\mathrm{CO}_{2}$ in outlet gases. Reduction was performed under $10 \% \mathrm{CH}_{4}$, and oxidation under $5 \% \mathrm{~N}_{2}$ and $5 \% \mathrm{O}_{2}$ in $\mathrm{He}$ was performed for laboratory-scale and ton-scale batches

the perovskite OCM systems is to achieve a homogeneous sintering temperature at desired values, and the fact that the final product's performance is greatly and sensitively affected by this parameter. Production of granulates with high ratios of crystalline perovskite phases in large scale needs further optimization in order to better homogenize formed crystalline phases, most importantly through optimization of large-scale calcination procedure. 
Acknowledgements The work presented in this article is conducted as part of the European Union Seventh Framework Programme (FP7/ 2007-2013) under Grant agreement no 608571 (Project acronym SUCCESS)

Open Access This article is distributed under the terms of the Creative Commons Attribution 4.0 International License (http://creative commons.org/licenses/by/4.0/), which permits unrestricted use, distribution, and reproduction in any medium, provided you give appropriate credit to the original author(s) and the source, provide a link to the Creative Commons license, and indicate if changes were made.

\section{References}

1. Hou L, Yu Q, Wang K, Wang T, Yang F, Zhang S. Oxygen storage capacity of substituted $\mathrm{YBaCo}_{4} \mathrm{O}_{7}+\mathrm{d}$ oxygen carriers. J Therm Anal Calorim. 2018;137(1):317-25. https://doi.org/10. 1007/s10973-018-7903-6.

2. Pishahang M, Larring Y, Adánez J, Gayán P, Sunding $\mathrm{M}$. $\mathrm{Fe}_{2} \mathrm{O}_{3}-$ $\mathrm{Al}_{2} \mathrm{O}_{3}$ oxygen carrier materials for chemical looping combustion, a redox thermodynamic and thermogravimetric evaluation in the presence of H2S. J Therm Anal Calorim. 2018;134(3):1739-48. https://doi.org/10.1007/s10973-018-7422-5.

3. Larring Y, Braley C, Pishahang M, Andreassen KA, Bredesen R. Evaluation of a mixed $\mathrm{Fe}-\mathrm{Mn}$ oxide system for chemical looping combustion. Energy Fuels. 2015;29(5):3438-45. https://doi.org/ 10.1021/acs.energyfuels.5b00048.

4. Ksepko E, Łabojko G. Effective direct chemical looping coal combustion with bi-metallic $\mathrm{Fe}-\mathrm{Cu}$ oxygen carriers studied using TG-MS techniques. J Therm Anal Calorim. 2014;117(1):151-62. https://doi.org/10.1007/s10973-014-3674-X.

5. Wang $\mathrm{Y}$, Wang $\mathrm{X}$, Hua $\mathrm{X}$, Zhao $\mathrm{C}$, Wang $\mathrm{W}$. The reduction mechanism and kinetics of $\mathrm{Fe}_{2} \mathrm{O}_{3}$ by hydrogen for chemicallooping hydrogen generation. $\mathrm{J}$ Therm Anal Calorim. 2017;129(3):1831-8. https://doi.org/10.1007/s10973-017-6267-7.

6. Ksepko E, Babinski P, Evdou A, Nalbandian L. Studies on the redox reaction kinetics of selected, naturally occurring oxygen carrier. J Therm Anal Calorim. 2015;124(1):137-50. https://doi. org/10.1007/s10973-015-5107-x.

7. Fossdal A, Bakken E, Oye BA, Schoning C, Kaus I, Mokkelbost $\mathrm{T}$, et al. Study of inexpensive oxygen carriers for chemical looping combustion. Int J Greenh Gas Control. 2011;5(3):483-8. https://doi.org/10.1016/j.ijggc.2010.08.001.

8. Mohammad Pour N, Azimi G, Leion H, Rydén M, Lyngfelt A. Production and examination of oxygen-carrier materials based on manganese ores and $\mathrm{Ca}(\mathrm{OH})_{2}$ in chemical looping with oxygen uncoupling. AIChE J. 2014;60(2):645-56. https://doi.org/10. 1002/aic.14273.

9. Jacobs M, Van Noyen J, Larring Y, McCann M, Pishahang M, Amini $\mathrm{S}$, et al. Thermal and mechanical behaviour of oxygen carrier materials for chemical looping combustion in a packed bed reactor. Appl Energy. 2015;157:374-81. https://doi.org/10. 1016/j.apenergy.2015.04.053.

10. Bakken E, Norby T, Stølen S. Nonstoichiometry and reductive decomposition of $\mathrm{CaMnO}_{3-\delta}$. Solid State Ion. 2005;176(1-2):217-23. https://doi.org/10.1016/j.ssi.2004.07.001.

11. Bakken E, Boerio-Goates J, Grande T, Hovde B, Norby T, Rørmark L, et al. Entropy of oxidation and redox energetics of $\mathrm{CaMnO}_{3-\delta}$. Solid State Ion. 2005;176(29-30):2261-7. https:// doi.org/10.1016/j.ssi.2005.06.009.

12. Arjmand M, Hedayati A, Azad A-M, Leion H, Rydén M, Mattisson T. $\mathrm{Ca}_{\mathrm{x}} \mathrm{La}_{1}-\mathrm{xMn}_{1}-\mathrm{yMyO}_{3-\delta}(\mathrm{M}=\mathrm{Mg}, \mathrm{Ti}, \mathrm{Fe}$, or $\mathrm{Cu})$ as oxygen carriers for chemical-looping with oxygen uncoupling
(CLOU). Energy Fuels. 2013;27(8):4097-107. https://doi.org/10. 1021/ef3020102.

13. Galinsky N, Mishra A, Zhang J, Li F. $\mathrm{Ca}_{1}-\mathrm{xAxMnO}_{3}(\mathrm{~A}=\mathrm{Sr}$ and $\mathrm{Ba}$ ) perovskite based oxygen carriers for chemical looping with oxygen uncoupling (CLOU). Appl Energy. 2015;157:358-67. https://doi.org/10.1016/j.apenergy.2015.04. 020 .

14. Arjmand M, Kooiman RF, Rydén M, Leion $H$, Mattisson $T$, Lyngfelt A. Sulfur tolerance of $\mathrm{Ca}_{\mathrm{x}} \mathrm{Mn}_{1}-\mathrm{yMyO}_{3-\delta}(\mathrm{M}=\mathrm{Mg}$, Ti $)$ perovskite-type oxygen carriers in chemical-looping with oxygen uncoupling (CLOU). Energy Fuels. 2014;28(2):1312-24. https:// doi.org/10.1021/ef402383v.

15. Pishahang M, Larring Y, McCann M, Bredesen R. $\mathrm{Ca}_{0.9} \mathrm{Mn}_{0.5-}$ $\mathrm{Ti}_{0.5} \mathrm{O}_{3-\delta}$ : a suitable oxygen carrier material for fixed-bed chemical looping combustion under syngas conditions. Ind Eng Chem Res. 2014;53(26):10549-56. https://doi.org/10.1021/ ie $500928 \mathrm{~m}$

16. Thoréton V, Pishahang M, Mokkelbost T, Wiik K, Larring Y. Microstructural stability of tailored $\mathrm{CaMn}_{0.875}-\mathrm{xFexTi}_{0.125} \mathrm{O}_{3-\delta}$ perovskite oxygen carrier materials for chemical looping combustion. Energy Technol. 2017;5(9):1579-87. https://doi.org/10. 1002/ente.201600792.

17. Källén $M$, Rydén $M$, Dueso $C$, Mattisson $T$, Lyngfelt $A$. $\mathrm{CaMn}_{0.9} \mathrm{Mg}_{0.1} \mathrm{O}_{3-\delta}$ as oxygen carrier in a gas-fired $10 \mathrm{~kW}$ th chemical-looping combustion unit. Ind Eng Chem Res. 2013;52(21):6923-32. https://doi.org/10.1021/ie303070h.

18. Leion H, Larring Y, Bakken E, Bredesen R, Mattisson T, Lyngfelt A. Use of $\mathrm{CaMn}_{0.875} \mathrm{Ti}_{0.125} \mathrm{O}_{3}$ as oxygen carrier in chemicallooping with oxygen uncoupling. Energy Fuels. 2009;23:5276-83. https://doi.org/10.1021/ef900444d.

19. Abad A, García-Labiano F, Gayán P, de Diego LF, Adánez J. Redox kinetics of $\mathrm{CaMg}_{0.1} \mathrm{Ti}_{0.125} \mathrm{Mn}_{0.775} \mathrm{O}_{2.9-\delta}$ for chemical looping combustion (CLC) and chemical looping with oxygen uncoupling (CLOU). Chem Eng J. 2015;269:67-81. https://doi. org/10.1016/j.cej.2015.01.033.

20. Cabello A, Abad A, Gayán P, de Diego LF, García-Labiano F, Adánez J. Effect of operating conditions and $\mathrm{H}_{2} \mathrm{~S}$ presence on the performance of $\mathrm{CaMg}_{0.1} \mathrm{Mn}_{0.9} \mathrm{O}_{3-\delta}$ perovskite material in chemical looping combustion (CLC). Energy Fuels. 2014;28(2):1262-74. https://doi.org/10.1021/ef4020718.

21. Sundqvist $\mathrm{S}$, Leion $\mathrm{H}$, Rydén $\mathrm{M}$, Lyngfelt $\mathrm{A}$, Mattisson $\mathrm{T}$. $\mathrm{CaMn}_{0.875} \mathrm{Ti}_{0.125} \mathrm{O}_{3-\delta}$ as an oxygen carrier for chemical-looping with oxygen uncoupling (CLOU)—solid-fuel testing and sulfur interaction. Energy Technol. 2013;1(5-6):338-44. https://doi.org/ 10.1002/ente.201300007.

22. Hallberg P, Jing D, Rydén M, Mattisson T, Lyngfelt A. Chemical looping combustion and chemical looping with oxygen uncoupling experiments in a batch reactor using spray-dried $\mathrm{CaMn}_{1-\text { - }}$ ${ }_{x} \mathrm{M} \mathrm{xO}_{3-\delta}(\mathrm{M}=\mathrm{Ti}, \mathrm{Fe}, \mathrm{Mg})$ particles as oxygen carriers. Energy Fuels. 2013;27(3):1473-81. https://doi.org/10.1021/ef3013618.

23. Jing D, Jacobs M, Hallberg P, Lyngfelt A, Mattisson T. Development of $\mathrm{CaMn}_{0.775} \mathrm{Mg}_{0.1} \mathrm{Ti}_{0.125} \mathrm{O}_{3-\delta}$ oxygen carriers produced from different Mn and Ti sources. Mater Des. 2016;89:527-42. https://doi.org/10.1016/j.matdes.2015.09.117.

24. Galinsky N, Sendi M, Bowers L, Li F. $\mathrm{CaMn}_{1-\mathrm{x}} \mathrm{BxO}_{3-\delta}(\mathrm{B}=\mathrm{Al}$, $\mathrm{V}, \mathrm{Fe} \mathrm{Co}$, and $\mathrm{Ni}$ ) perovskite based oxygen carriers for chemical looping with oxygen uncoupling (CLOU). Appl Energy. 2016;174:80-7. https://doi.org/10.1016/j.apenergy.2016.04.046.

25. Leion H, Larring Y, Bakken E, Bredesen R, Mattisson T, Lyngfelt A. Use of $\mathrm{CaMn}_{0.875} \mathrm{Ti}_{0.125} \mathrm{O}_{3}$ as oxygen carrier in chemicallooping with oxygen uncoupling. Energy Fuels. 2009;23(10):5276-83. https://doi.org/10.1021/ef900444d.

26. Thoréton V, Darell O, Spjelkavik A, Sunding M, Mokkelbost T, Pishahang M, et al. Manufacturing of perovskite oxygen carriers by spray granulation for chemical looping combustion. Energy 
Technol. 2017;5(11):2119-27. https://doi.org/10.1002/ente. 201700201.

27. Stølen S, Grande T. Trends in enthalpy of formation. Chemical thermodynamics of materials. New York: Wiley; 2004. p. $197-227$.

28. Taguchi H, Nakade K, Yosinaga M, Kato M, Hirota K. Methane oxidation on perovskite-type $\mathrm{Ca}\left(\mathrm{Mn}_{1-\mathrm{x}} \mathrm{Ti}_{\mathrm{x}}\right) \mathrm{O}_{3-\delta}$. J Am Ceram Soc. 2007;91(1):308-10. https://doi.org/10.1111/j.1551-2916. 2007.02028.x.

29. Rydén M, Lyngfelt A, Mattisson T. $\mathrm{CaMn}_{0.875} \mathrm{Ti}_{0.125} \mathrm{O}_{3}$ as oxygen carrier for chemical-looping combustion with oxygen uncoupling (CLOU) - experiments in a continuously operating fluidized-bed reactor system. Int J Greenh Gas Control. 2011;5(2):356-66. https://doi.org/10.1016/j.ijggc.2010.08.004.

30. Fossdal A, Darell O, Lambert A, Schols E, Comte E, Leenman R, et al. Study of dimensional changes during redox cycling of oxygen carrier materials for chemical looping combustion. Energy Fuels. 2015;29(1):314-20. https://doi.org/10.1021/ ef502004k.

31. Pishahang M, Larring Y, Sunding MF, Jacobs M, Snijkers F. Performance of perovskite-type oxides as oxygen-carrier materials for chemical looping combustion in the presence of $\mathrm{H}_{2} \mathrm{~S}$. Energy Technol. 2016;4:1305-16. https://doi.org/10.1002/ente. v4.10/.

32. Pishahang M, Larring Y, Sunding M, Jacobs M, Snijkers F. Cover picture: performance of perovskite-type oxides as oxygen-carrier materials for chemical looping combustion in the presence of $\mathrm{H}_{2} \mathrm{~S}$
(Energy Technol. 10/2016). Energy Technol. 2016;4(10):1125. https://doi.org/10.1002/ente.201600397.

33. Taguchi H. Electrical property of K2NiF4-type Ca2(Mn12xNbx)O4. Mater Res Bull. 2001;36:1361-7.

34. Giesber HG, Pennington WT, Kolis JW. Redetermination of $\mathrm{CaMn}_{2} \mathrm{O}_{4}$. Acta Crystallogr Sect C. 2001;57(4):329-30. https:// doi.org/10.1107/S0108270100011367.

35. Nakade K, Hirota K, Kato M, Taguchi H. Effect of the $\mathrm{Mn}^{3+}$ ion on electrical and magnetic properties of orthorhombic perovskitetype $\mathrm{Ca}\left(\mathrm{Mn}_{1-\mathrm{x}} \mathrm{Tix}\right) \mathrm{O}_{3-\delta}$. Mater Res Bull. 2007;42(6):1069-76. https://doi.org/10.1016/j.materresbull.2006.09.013.

36. Yashima M, Ali R. Structural phase transition and octahedral tilting in the calcium titanate perovskite CaTiO3. Solid State Ion. 2009;180(2-3):120-6. https://doi.org/10.1016/j.ssi.2008.11.019.

37. Leonidova EI, Leonidov IA, Patrakeev MV, Kozhevnikov VL. Oxygen non-stoichiometry, high-temperature properties, and phase diagram of $\mathrm{CaMnO}_{3-\delta}$. J Solid State Electrochem. 2011;15(5):1071-5. https://doi.org/10.1007/s10008-010-1288-1.

38. Jing D, Snijkers F, Hallberg P, Leion H, Mattisson T, Lyngfelt A. Effect of production parameters on the spray-dried calcium manganite oxygen carriers for chemical-looping combustion. Energy Fuels. 2016;30(4):3257-68. https://doi.org/10.1021/acs. energyfuels. $5 \mathrm{~b} 02872$.

Publisher's Note Springer Nature remains neutral with regard to jurisdictional claims in published maps and institutional affiliations. 